ВПЛИВ ОСВІТНЬОГО РІВНЯ ПІДГОТОВКИ

ТА ПРОФЕСІЙНОЇ КВАЛІФІКАЦІЇ ПЕРСОНАЛУ НА ФОРМУВАННЯ

ТОВАРНОÏ ПОЛІТИКИ ТА РОЗВИТОК

ІННОВАЦІЙНОГО ПОТЕНЦІАЛУ ПІДПРИЕМСТВА

\title{
INFLUENCE OF EDUCATION LEVEL AND PROFESSIONAL QUALIFICATION OF EMPLOYEE ON COMMODITY POLICY FORMATION AND INNOVATIVE POTENTIAL DEVELOPMENT OF ENTERPRISE
}

УДК: 658:331:338.001.36

https://doi.org/10.32843/bses.60-24

\section{Шитікова Л.В.}

к.е.н., доцент,

доцент кафедри менеджменту

Національний університет

«Запорізька політехніка»

Борисенко О.є.

к.е.н., доцент каредри

маркетингу та логістики

Національний університет

«Запорізька політехніка»

Shitikova Larysa

National University

«Zaporizhzhia Polytechnic»

Borysenko Olena

National University

«Zaporizhzhia Polytechnic»

\begin{abstract}
Статтю присвячено визначенню впливу якісного рівня підготовки працівників на формування товарної політики та розвиток інноваційного потенціалу підприємства. Проведений аналіз освітнього рівня підготовки спеціалістів на підприємствах агропромислового комплексу дав змогу встановити, що частка таких фрахівців занизька та не може задовольнити потреби підприємств. Запропоновано використовувати інтенсивний підхід, який ірунтується на комплексному періодичному оцінюванні спеціалістів за методом, що ув'язує їхній рівень освіти та відповідність профресійної квалісрікації займаній посаді зі стажем роботи та кількістю впроваджених винаходів і раціоналізаторських пропозицій та вимагає: повного та ефективного використання персоналу; створення умов, які приваблюють фрахівців високої кваліфрікації; фрормування стабільного високоінтелектуального колективу. Це сприятиме розвитку інноваційного потенціалу підприємства та формуванню його товарної інноваційної політики.

Ключові слова: освітній рівень підготовки, просресійна квалісікація, персонал, товарна політика підприємства, інноваційний потенчіал, ефективне управління.
\end{abstract}

Статья посвящена определению влияния качественного уровня подготовки работников на формирование товарной политики и развитие инновационного потенциала предприятия. Проведенный анализ уровня образования специалистов на предприятиях агропромышленного комплекса позволил установить, что доля таких работников низкая и не может удовлетворить потребности предприятий. Предложено использовать интенсивный подход, основанный на комплексной периодической оценке специалистов по методу, который увязывает их уровень образования и соответствие профрессиональной квалификации занимаемой должности со стажем работы и количеством внедренных изобретений и рационализаторских предложений и требует: полного и эффрективного использования персонала; создания условий, которые привлекают специалистов высокой квалификации; формирования стабильного высокоинтеллектуального коллектива. Это будет способствовать развитию инновационного потенциала предприятия и формированию его товарной инновационной политики.

Ключевые слова: уровень образования, профрессиональная квалификация, персонал, товарная политика предприятия, инновационный потенциал, эффрективное управление.

The article is devoted to the current problem of assessing the influence of the qualitative level of employees on the formation of commodity policy and the development of the innovative potential of the enterprise. The work has proved that since the main goal of the enterprises development is the efficiency of economic activities, the increase in productivity is achieved by the more active use of highly qualified employee, the most important quality characteristic of which is the educational factor. An analysis of influence of the workers education level who belong to the specialists category in enterprises of the agroindustrial complex was carried out, since this type of employee who primarily affect the formation of commodity innovation policies and the innovative development of the enterprise. The results of the resurch shows that the fate of specialists with higher education in strict conditions of the modern situation on the market of goods and services cannot satisfy the needs of enterprises to achieve the established goals. The solution to the issue of improving the quality of specialists is based on an intensive approach, which is based on an integrated periodic assessment of specialists and requires: full and effective use of staff; providing conditions that attract highly qualified specialists for high-performance labor; formation of a stable highly intelligent team. A negative consequence of inaction is a decrease in the level of innovative capacity and inefficient commodity policies. The scientific novelty of the study is the improvement of the methodological approach to assessing the educational level and professional qualifications of specialists, which concludes their level of education and compliance with the professional qualifications of the position with work experience and the number of inventions and best proposals. This will contribute not only to the qualitative development of the enterprise employee, but also creates the basis for making effective management decisions on the strategy for developing the innovative potential of the enterprise and forming its effective commodity innovation policy. The practical importance of the obtained results, lies in the possibility of their use in the formation of an effective program of activities to develop the innovative potential of enterprise employee.

Key words: level of education, professional qualification, employee, product policy of the enterprise, innovation potential, effective management.

Постановка проблеми. Сучасні підприємства срункціонують у складних динамічних умовах. Це потребує вирішення проблем, пов'язаних із позиціонуванням товарів та послуг, які надаються підприємством, та зростанням їхньої конкурентоспроможності, що забезпечує результативність та стабільність роботи суб'єкта господарювання. Складність і динаміка соціально-економічних процесів вимагають розроблення нових підходів до використання та управління трудовими ресур- сами, зокрема їх освітнім рівнем та профресійною кваліфрікацією як основної якісної характеристики, що фрормується відповідним освітнім степенем. Пошук економічно вигідної стратегії та систематичного підходу зумовлює здійснення досліджень і визначає актуальність вибраної теми.

Аналіз останніх досліджень і публікацій. Активна інноваційна діяльність, ефективна товарна політика важливі для забезпечення соціально-економічного розвитку України і зумов- 
люють зацікавленість науковців та практиків у здійсненні досліджень за цим напрямом. Аналіз сучасних досліджень і публікацій дає змогу стверджувати, що вибраній проблемі приділяють значну увагу вітчизняні і закордонні науковці: Г.В. Осовська і О.В. Крушельницька [1], А.Я. Кібанов [2], Н.А. Пиличев, Т.В. Донченко, Є.П. Качан, Д.Г. Шушпанов [3], О.Ф. Морозов, В.О. Гончар [4] та ін. Водночас масштабність проблем актуалізує дослідження, що стосуються якісного рівня працюючих на підприємстві, зокрема рівня їх освітньої та професійної кваліфікації. Як зазначають А.В. Череп, Т.В. Пуліна, О.Г. Череп, «важливою характеристикою персоналу, що веде інноваційну діяльність, є його кваліфрікаційний рівень» [5, с. 270].

Розв'язання проблеми результативного господарювання, конкурентоспроможності та сталого розвитку підприємств неможливо без вирішення проблеми організації ефективного управління. Центральним питанням кожного підприємства в сучасних умовах рефрормування економіки України $€$ загальна система управління, ключовим складником якої $€$ підсистема управління людськими ресурсами. Як зазначають Є.П. Качан та Д.Г. Шушпанов, «вироблення і прийняття ... рішень щодо підвищення ефективності використання трудових ресурсів - складний процес, який передбачає необхідність його розгляду з позицій єдності відтворення, розподілу і використання робочої сили» [3, с. 12]. Незважаючи на значні досягнення в теорії та практиці управління, існує низка проблем, які залишаються предметом дискусій та обговорень учених-економістів і практиків.

Постановка завдання. Мета статті полягає у визначенні сучасних підходів до оцінки впливу освітнього рівня підготовки та професійної кваліфікації працюючих на розвиток інноваційного потенціалу і формування ефективної товарної політики агропромислових підприємств.

Виклад основного матеріалу дослідження. Визначальною ознакою формування «нової» економіки є використання нових знань як самостійного фрактору виробництва [6, с. 41]. Даний аспект оцінює, наскільки персонал підприємства здатний виконувати поставлені перед ним цілі.

У сучасних умовах господарювання інноваційний потенціал та вдала політика у сорері товарів і послуг є основою розвитку, оскільки визначає можливості підприємства, які залежать від специфіки, галузевих особливостей, масштабів діяльності суб'єкта господарювання. Тільки застосування комплексних економічних методів може дати сьогодні необхідний економічний ефект і вивести підприємство на новий рівень розвитку [7, с. 71].

Ефективна політика суб'єкта господарювання у сорері товарів та послуг залежить від швидкості реагування на зміни як внутрішнього, так і зовнішнього середовища, вміння пристосувати потенційні можливості підприємства до сучасної ситуації конкурентного ринку, зменшення конкурентного впливу. Вихід за межи своєї країни тягне за собою додаткові проблеми, на які слід звернути увагу. Для підприємств, які працюють на зовнішній ринок, важливим стає вміння працювати в умовах багатонаціональної команди фрахівців, які мають свої погляди на роботу, яку треба виконувати, культурні відмінності тощо. Сучасний склад працівників підприємства, які займають посади спеціалістів, повинен уміти консолідувати зусилля своїх працівників для підвищення результативності сумісної праці, отримання багаторазового синергетичного ефректу.

Поряд із фрінансовими, матеріальними, енергетичними, технологічними ресурсами на сучасному підприємстві важливою частиною виробничих ресурсів є людські ресурси. Людський капітал $€$ ключовим чинником фрормування всіх інших створених людьми видів капіталу, головною умовою стабільності та успішного розвитку господарюючого суб'єкта, таким чином, ефективне використання персоналу підприємства безпосередньо вплине на ефективність діяльності суб'єкта господарювання та підвищить ринкову вартість його капіталу. В умовах десріциту трудових ресурсів найважливішим напрямом у ссрері їх фрормування повинна стати політика ефективного використання. Вирішення цієї проблеми є запорукою стабілізації фрункціонування підприємства [8, с. 258].

Інноваційний процес включає виявлення, вимірювання, збір, аналіз, інтерпретацію, передачу і прийом інформації, яка необхідна науковцям (персоналу, що займається науковими розробками, дослідженнями) для виконання їхніх функцій. Для здійснення зазначених функцій персонал займається виявленням, вимірюванням, збором, аналізом, інтерпретацією, передачею і прийомом інорормації. Ступінь успішності та результативності роботи науковців залежить від «...індивідуальних здібностей і ступеню підготовки, бажань..» [5, с. 270], інноваційної активності, сприятливості до нововведень.

Спеціалісти підприємства - це представники однієї з профресійних груп персоналу, які мають глибоку фахову підготовку, володіють спеціальними знаннями та навичками для виконання робіт, зумовлених як основною, так і допоміжною діяльністю підприємства, мають вищу та профресійну освіту, досвід роботи у певній сфері господарства.

Персонал, що займається дослідницькою роботою, перевіряється на відповідність займаній посаді. Особливу увагу необхідно приділяти аналізу якісного складу за рівнем кваліфікації як ключовій характеристиці забезпеченості підприємства кадрами найважливіших професій 3 найвищою кваліфрікацією. 
Аграрні підприємства можуть істотно відрізнятися за професійним складом своїх працівників, що зумовлено їх різною спеціалізацією та неоднаковим ступенем диверсифікації виробництва [1, с. 218].

На прикладі підприємств агропромислового комплексу Василівського району Запорізької області проаналізуємо структуру розподілу спеціалістів за період 2016-2019 рр. за їх освітнім рівнем підготовки (табл. 1).

Питома вага освітнього складу спеціалістів на різних підприємствах агропромислового комплексу Василівського району Запорізької області не однакова, що спостерігаємо на діаграмах рис. 1.

Найбільшу питому вагу на більшості агропідприємств становить персонал із професійною освітою, виняток становлять ТОВ «АПК «Істок» та TOB «Промінь», де спостерігається найбільша питома вага спеціалістів із вищою освітою. У 2019 р. у ТОВ «Промінь» така тенденція збері- гається, і показник питомої ваги робітників із професійною освітою хоча й підвищується, але дорівнює 44,83\% проти 44,12\% у 2018 р., що менше, ніж питома вага робітників із вищою освітою $(48,28 \%)$.

Аналіз динаміки чисельності працівників із вищою освітою на підприємствах АПК за період 2016-2019 рр. (рис. 2) показує різке зростання таких працівників тільки в ТОВ «Промінь». Це пояснюється наявністю на підприємстві підвищеного попиту на висококваліфікованих фрахівців. Водночас спостерігаємо зниження даного показника в ТОВ «АПК «Істок» та СВК «Орлянський». Агропідприємство ПОП «АФ «Злагода» на протязі досліджуваного періоду практично не змінює даний показник.

Як показує аналіз динаміки чисельності працівників із професійною освітою на підприємствах АПК за період 2016-2019 рр. (рис. 3), майже на всіх підприємствах, окрім ТОВ «АПК «Істок» спостерігаємо зменшення чисельності таких спеціалістів.

Структура спеціалістів за їх освітнім рівнем підготовки

Таблиця 1

в агропідприємствах Василівського району Запорізької області за період 2016-2019 рр., \%

\begin{tabular}{|c|c|c|c|c|c|c|c|c|c|c|c|c|}
\hline \multirow[b]{2}{*}{$\begin{array}{l}\text { Найменування } \\
\text { господарства }\end{array}$} & \multicolumn{3}{|c|}{2016} & \multicolumn{3}{|c|}{2017} & \multicolumn{3}{|c|}{2018} & \multicolumn{3}{|c|}{2019} \\
\hline & 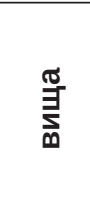 & 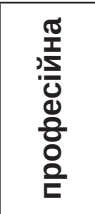 & 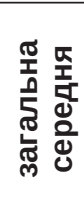 & 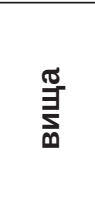 & 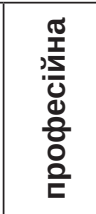 & 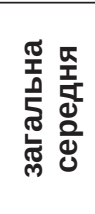 & 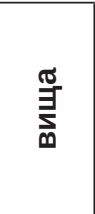 & 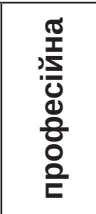 & 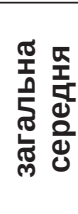 & 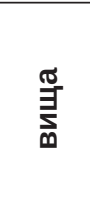 & 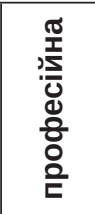 & 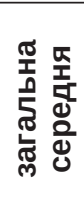 \\
\hline ПОП «АФ ім. Чапаєва» & 30,0 & 50,0 & 20,0 & 22,22 & 55,56 & 22,22 & 26,32 & 52,63 & 21,2 & 29,4 & 47,0 & 23,6 \\
\hline СВК «Орлянський» & 35,29 & 64,71 & - & 31,25 & 68,75 & - & 26,7 & 73,3 & - & 42,85 & 57,15 & - \\
\hline ПОП «АФ «Злагода» & 42,86 & 57,14 & - & 27,27 & 72,73 & - & 33,33 & 66,67 & - & 33,33 & 66,67 & - \\
\hline ТОВ «АПК ІстоК» & 58,06 & 41,94 & - & 70,58 & 29,42 & - & 53,33 & 46,67 & - & 50,0 & 50,0 & - \\
\hline ТОВ «Промінь» & 41,67 & 50,0 & 8,33 & 28,0 & 68,0 & 4,0 & 50,00 & 44,12 & 5,88 & 48,28 & 44,82 & 6,9 \\
\hline
\end{tabular}

Джерело: складено авторами

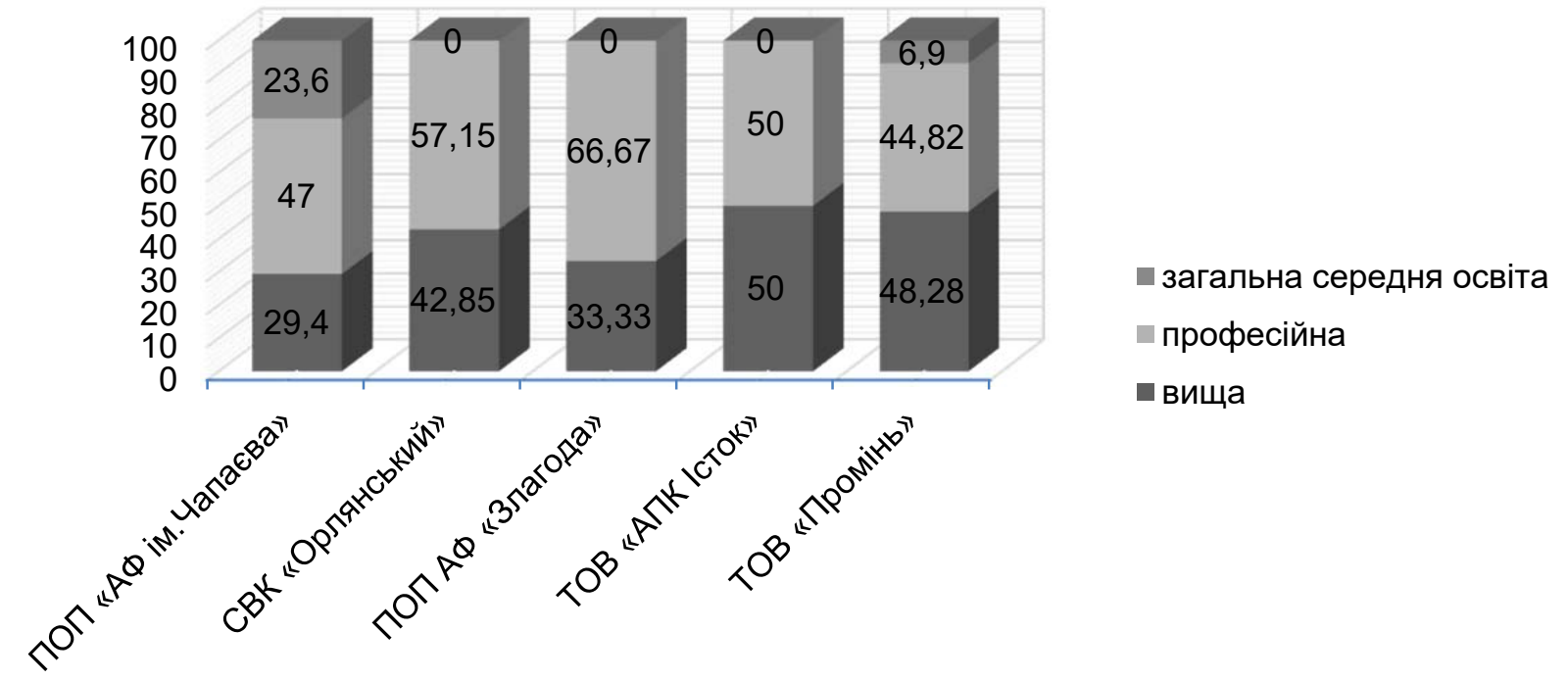

Рис. 1. Структура розподілу спеціалістів за освітнім рівнем підготовки в агропідприємствах Василівського району Запорізької області в 2019 р.

Джерело: складено авторами 


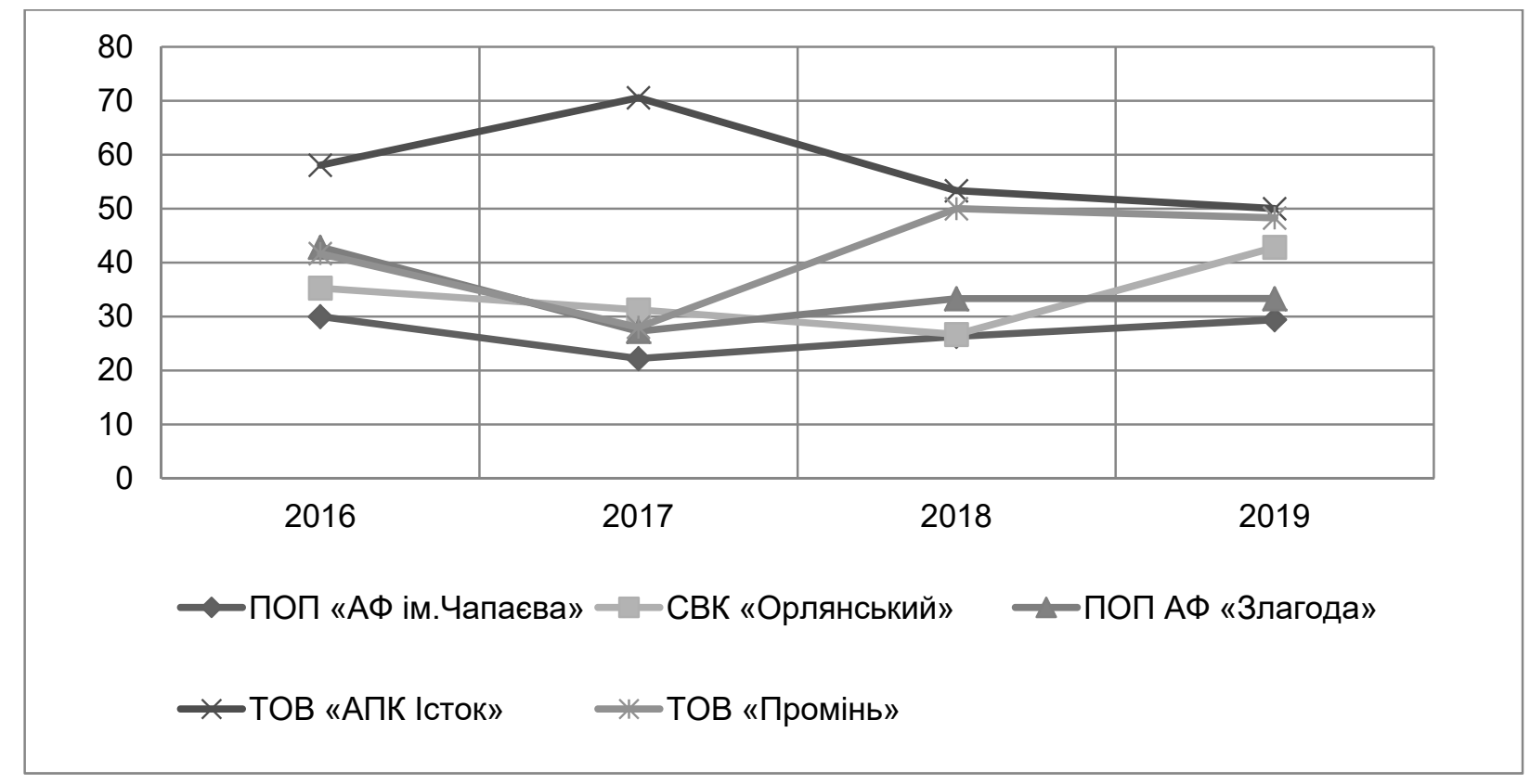

Рис. 2. Динаміка змін частки спеціалістів із вищою освітою на підприємствах АПК Василівського району Запорізької області в 2016-2019 рр.

Джерело: складено авторами

Однак якщо на підприємствах ПОП «АФ ім. Чапаєва» та ТОВ «Промінь» частка спеціалістів, які мають лише рівень профресійної освіти менше 50\%, то на інших цей показник перевищує це значення в 2019 р. Негативним чинником $€$ те, що на цих підприємствах є частка спеціалістів, що мають лише загальну середню освіту. Так, на ПОП «АФ ім. Чапаєва» частка таких фрахівців становить майже 24\% на відміну від ТОВ «Промінь» (майже 7\%). Це негативно впливає на інноваційний потенціал підприємства та його товарну політику.

У цілому можна стверджувати, що виявлений рівень фрахівців із вищою освітою на підприємствах АПК Василівського району Запорізької області в суворих умовах сучасної ситуації на ринку товарів та послуг не може повною мірою задовольнити потреби підприємств у необхідному інноваційному розвитку й ефективній товарній політиці.

Водночас такий аналіз повинна доповнювати перевірка відповідності отриманої професійної кваліфрікації кожного спеціаліста його фрунціональним обов'язкам. Таке співставлення на вказаних підприємствах проводиться зрідка, що уповільнює процес фрормування дієвої програми розвитку персоналу.

Певним вирішенням виявленої проблеми $\epsilon$ постійне й своєчасне підвищення кваліфрікації, яке сприяє поглибленню і всебічному розширенню виробничих навичок та вмінь, яких потребує сучасне виробництво. Досліджувані підприємства практикують підвищення кваліфрікації своїх працівників, що дає можливість професійно вирішувати поставлені перед ними виробничі завдання, однак відсутність постійного моніторингу та інтенсифікації цього процесу не дає змоги повною мірою привести представлені показники у відповідність із сучасними ринковими реаліями, що негативно впливає на фрормування товарної інноваційної політики та уповільнює процес розвитку інноваційного потенціалу підприємства.

Пропонується для вирішення питання поліпшення якісного рівня фрахівців використовувати інтенсивний підхід, який ґрунтується на комплексному періодичному оцінюванні спеціалістів та вимагає:

- повного та еорективного використання персоналу;

- створення умов, які приваблюють фрахівців високої кваліфрікації для високопродуктивної праці;

- фрормування стабільного високоінтелектуального колективу.

Узагальнюючим показником, за яким пропонується здійснювати комплексне оцінювання спеціалістів, є коефіцієнт, який ураховуватиме оцінку відповідності освітнього рівня та професійної кваліфрікації фрахівця, його особистісних характеристик та результатів праці:

$$
K_{в}=K_{\text {орпк }} \cdot K_{\text {дя }}+K_{c к} \cdot K_{p}
$$

де $K_{в}-$ коефріцієнт відповідності робітника займаній посаді;

$K_{\text {орпк }}$ - коефріцієнт відповідності освітнього рівня та профресійної кваліфрікації;

$K_{\text {дя }}-$ коефріцієнт оцінки ділових якостей, що створюють необхідні передумови для виконання відповідних обов'язків; 


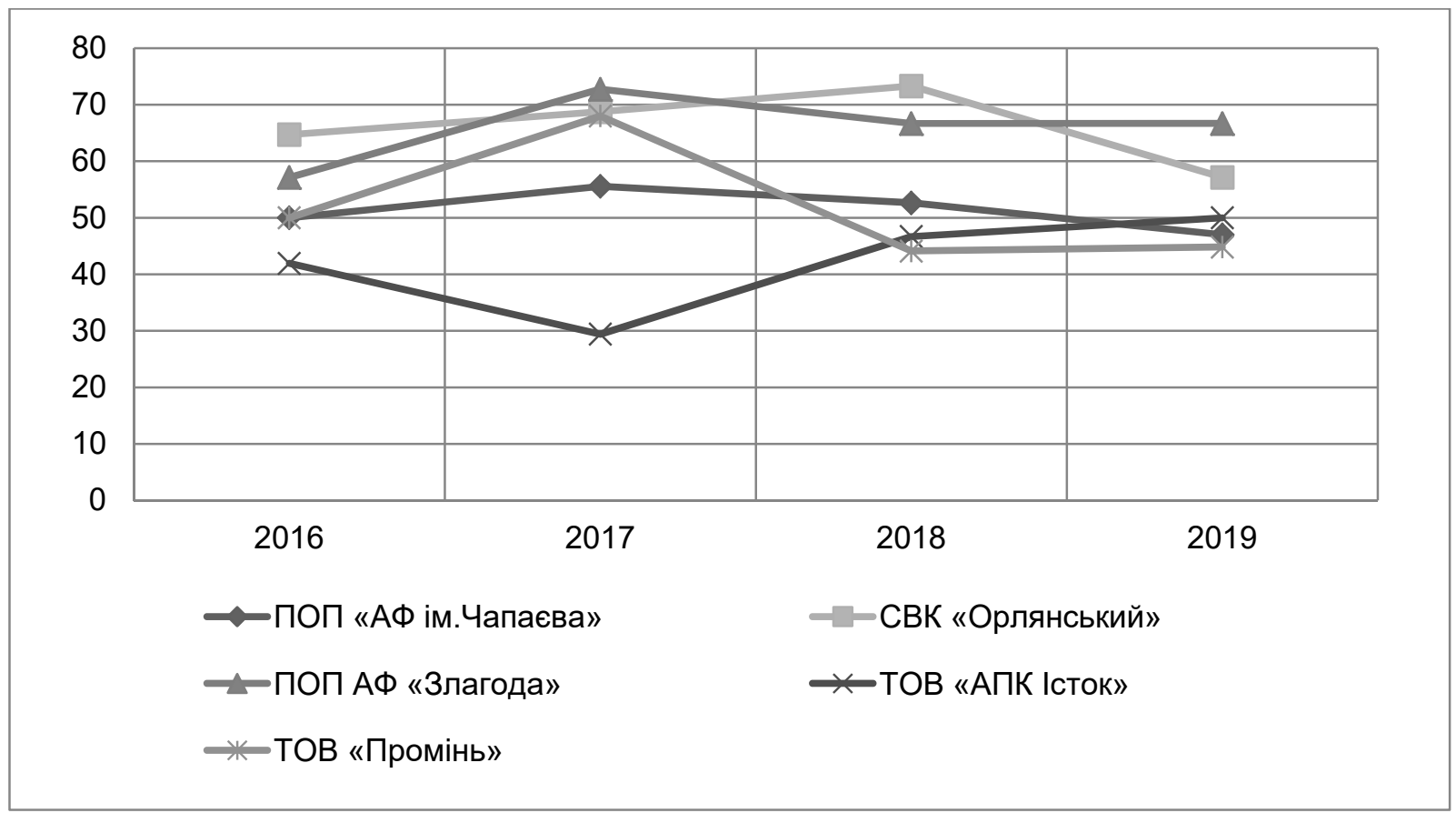

Рис. 3. Динаміка змін частки спеціалістів із професійною освітою на підприємствах АПК Василівського району Запорізької області в 2016-2019 рр.

Джерело: складено авторами

$K_{c \kappa}-$ коефріцієнт, що характеризує складність роботи;

$K_{p}-$ коесріцієнт, що відображує результативність роботи фрахівця.

Коесріцієнт відповідності освітнього рівня та професійної квалісрікації працівника може бути визначений за срормулою:

$$
K_{\text {орпк }}=\frac{O П K+C P+B}{5,3},
$$

де ОПК - оцінка рівня освіти та професійної кваліфрікації, приймаємо ОПК від 1 до 4. Тобто за рівнем освіти спеціалістів слід розподіляти на 3 групи: 1 - загальна середня (повна або незакінчена); 2 - профресійна; 3 - вища або незакінчена вища освіта. Номер групи, до якої відноситься працівник за рівнем освіти, визначає його оцінку за цією ознакою. Відповідність профресійної кваліфрікації займаній посаді додає ще 1;

СР - оцінка стажу роботи за фахом, приймаємо $\mathrm{CP}=0,25 ; 0,5 ; 0,75$ або 1 за табл. 2;

В - оцінка винахідництва та раціоналізаторської діяльності, приймаємо $\mathrm{B}=0,1 ; 0,2$ або 0,3 залежно від кількості винаходів: якщо винахід був один, то B = 0,1; два - 0,2; три і більше, то $\mathrm{R}=0,3$; 5,3 - сума максимальних оцінок за всіма показниками оцінки.

Усі інші показники визначаються за допомогою методу бальної оцінки та прийнятих на підприємстві відповідних критеріїв оцінювання.

Такий підхід дасть змогу не лише якісно оцінити освітній рівень та відповідність професійної квалі- фрікації спеціалістів підприємства, а й сорормувати об'єктивний план підвищення кваліфікації персоналу відповідно до стратегії розвитку інноваційного потенціалу та фрормування товарної політики підприємства.

Сьогодні необхідно компетентно управляти трудовими ресурсами, визначати продуктивні етапи управління і, використовуючи новітні наукові розробки та практичний узагальнений досвід вітчизняних та зарубіжних підприємств, створювати такий механізм управління трудовими ресурсами, який буде найефективнішим на конкретному підприємстві.

Робота фрахівців у цьому напрямі повинна узгодити інтереси різних груп працюючих, власників підприємств, власників майнових паїв та інших осіб, які зацікавлені в результативній роботі; визначити рівень якості; вибрати найвагоміші складники даної проблеми та вдосконалити методичні засади оцінки впливу результатів поліпшення процесу господарської діяльності для реалізації цілей. Як зазначають А.Я. Кібанов, Л.В. Івановська, О.О. Мітрофранова, управління зайнятістю в процесі використання персоналу полягає у цілеспрямованому регулюванні відносин між власниками підприємства, власниками майнових паїв та найманими працівниками, що забезпечує реалізацію економічних і неекономічних інтересів суб'єктів трудових відносин [2, с. 53]. Тому велике значення має спрямованість спільних зусиль та здійснення дій всіх учасників операційного процесу на забезпечення умов праці науковців, дослідників, у яких 
Оцінка стажу роботи працівників

\begin{tabular}{|c|c|c|c|c|}
\hline \multirow{2}{*}{$\begin{array}{c}\text { № групи } \\
\text { за стажем }\end{array}$} & \multirow{2}{*}{$\begin{array}{l}\text { Оцінка стажу, } \\
\text { СР }\end{array}$} & \multicolumn{3}{|c|}{$\begin{array}{c}\text { Стаж роботи за фрахом (кількість років) у працівника, } \\
\text { що має відповідний рівень освіти }\end{array}$} \\
\hline & & $\begin{array}{c}1 \text { група - } \\
\text { загальна середня }\end{array}$ & $\begin{array}{c}2 \text { група - } \\
\text { профресійна }\end{array}$ & $\begin{array}{c}3 \text { група - вища } \\
\text { або незакінчена вища }\end{array}$ \\
\hline 1 & 0,25 & $0-9$ & $0-5$ & $0-5$ \\
\hline 2 & 0,5 & $9-17$ & 5-13, понад 29 & 5-17, понад 29 \\
\hline 3 & 0,75 & 21-29, понад 29 & $13-17,21-29$ & $17-25$ \\
\hline 4 & 1 & $17-21$ & $17-21$ & $26-29$ \\
\hline
\end{tabular}

Джерело: запропоновано авторами

вони зможуть виконувати трудові фрункції, найбільш ефективно використовуючи свій досвід, професійні здібності, знання, навички, майстерність.

Науковий підхід до управління персоналом потребує врахування й активного використання організаційно-економічних, правових, технічних, соціально-психологічних та інших аспектів у їх сукупності та взаємозв'язку.

Висновки 3 проведеного дослідження. У роботі доведено, що головною метою розвитку підприємств є результативність господарської діяльності, яка досягається ефрективним використанням кадрового ресурсу, поліпшенням його освітнього рівня підготовки та професійної кваліфрікації, що впливає на розвиток інноваційного потенціалу та ефрективну політику підприємств у сорері товарів і послуг.

Аналіз освітнього рівня підготовки спеціалістів за досліджуваний період на агропідприємствах Запорізької області показав значення, які не відповідають сучасним вимогам ефективного менеджменту, що негативно впливає на ефективність управлінських зусиль. Для поліпшення своєї діяльності підприємствам необхідно ретельно розробляти та втілювати нові підходи до розвитку та залучення фрахівців високого освітнього та кваліфрікаційного рівнів, що дасть можливість вести господарську діяльність на високому конкурентоспроможному рівні.

Прагнення сучасних агропромислових підприємств підвищити економічну стійкість, інноваційний потенціал, конкурентоспроможність, отримати додатковий дохід спонукає більш відповідально підходити до оцінки діяльності спеціалістів, тому запропоновано в основу аналізу якісного складу спеціалістів покласти метод оцінки, що ув'язує їхній рівень освіти та відповідність професійної кваліфікації займаній посаді зі стажем роботи та кількістю впроваджених винаходів і раціоналізаторських пропозицій та вимагає: повного та ефективного використання персоналу; створення умов, які приваблюють фрахівців високої кваліфікації для високопродуктивної праці; фрормування стабільного високоінтелектуального колективу. Це сприятиме не лише якісному розвитку персоналу під- приємства, а й створює підґрунтя для прийняття ефрективних управлінських рішень щодо стратегії розвитку інноваційного потенціалу підприємства та формування його ефективної товарної інноваційної політики.

Незважаючи на те що досліджувані агропромислові підприємства роблять спроби щодо зростання ефективності своєї діяльності, намагаються підвищити конкурентоспроможність виробленої продукції, освоюють нові напрями ведення господарської діяльності, активно використовуючи ресурсний потенціал, використання запропонованого підходу дасть змогу не лише поліпшити використання кадрового потенціалу, а й одержати позитивний ефект і втримати цей результат як можна довше. Отримані результати можуть бути основою вдосконалення системи управління інноваційними процесами на підприємстві.

Подальшим напрямом досліджень уважаємо розроблення стратегії розвитку інноваційного потенціалу та вибір оптимального варіанта товарної інноваційної політики кожного підприємства 3 урахуванням індивідуальних особливостей їх умов господарювання.

\section{БІБЛІОГРАФІЧНИЙ СПИСОК:}

1. Крушельницька О.В., Мельничук Д.П. Управління персоналом : навчальний посібник. Київ : Кондор, 2006. 292 с.

2. Управление персоналом: теория и практика / А.Я. Кибанов и др. Социально-трудовые отношения, рынок труда и занятость персонала : учебно-практическое пособие. Москва : Проспект, 2012. 64 с.

3. Качан Є.П., Шушпанов Д.Г. Управління трудовими ресурсами : навчальний посібник Київ : Юридична книга, 2005. 358 с.

4. Морозов О.Ф., Гончар В.О. Система управління розвитком персоналу підприємства. Ефективна економіка. 2017. № 1. URL: http://www.economy.nayka. com.ua/?op=1\&z=5372.

5. Череп А.В., Пуліна Т.В., Череп О.Г. Інноваційний менеджмент : підручник. Київ : Кондор, 2014. 452 c.

6. Ушенко Н.В. Умови та фрактори підвищення продуктивності використання людського капіталу України. Економіка праці. 2008. № 5. С. 37-44. 
7. Антоненко Т.А. Зниження затрат - одна з пріоритетних стратегій діяльності підприємств. Тиждень науки : тези доп. наук.-практ. конф., м. Запоріжжя, 14-16 квітня 2014 р. / редкол.: Ю.М. Внуков (відп. ред.) та ін. Запоріжжя : ЗНТУ, 2014. Т. 3. С. 70-71.

8. Шитікова Л.В., Головатенко С.С. Формування управлінського потенціалу підприємства - ключова задача управління. Науковий вісник Ужгородського університету. Серія «Економіка». 2015. Вип. 2(46). С. 257-260.

\section{REFERENCES:}

1. Krusheljnycjka O.V., Meljnychuk D.P. (2006) Upravlinnja personalom [Personnel Management]. Kyiv: Kondor. (in Ukrainian)

2. Kibanov A. Ya., Ivanovskaya L.V., Mitrofanova E.A. (2012) Upravlenie personalom: teoriya i praktika. Sotsial'no-trudovye otnosheniya, rynok truda i zanyatost' personala [Personnel management: theory and practice. Social and labor relations, labor market and personnel employment]. Moscow: Prospekt. (in Russian)

3. Kachan Je. P., Shushpanov D.Gh. (2005) Upravlinnja trudovymy resursamy [Human resource management]. Kyiv. Vyrobnychyj Dim «Jurydychna knygha». (in Ukrainian)
4. Morozov O.F., Ghonchar V.O. (2017). Systema upravlinnja rozvytkom personalu pidpryjemstva [System of personal development at the enterprise]. Efektyvna ekonomika (electronic journal), no. 1. Available at: http://www.economy.nayka.com.ua/?op=1\&z=5372 (accessed 02 January 2021).

5. Cherep A.V., Pulina T.V., Cherep O.Gh. (2014) Innovacijnyj menedzhment [Innovation management]. Kyiv. Kondor. (in Ukrainian)

6. Ushenko N. V. (2008) Umovy ta faktory pidvyshhennja produktyvnosti vykorystannja ljudsjkogho kapitalu Ukrajiny [Conditions and factors for increasing the productivity of human capital use in Ukraine]. Ekonomika praci, no. 5, pp. 37-44.

7. Antonenko T.A. (2014) Znyzhennja zatrat - odna z priorytetnykh strateghij dijaljnosti pidpryjemstv [Cost reduction is one of the priority strategies of enterprises]. Proceedings of the Tyzhdenj nauky (Ukraine, Zaporizhzhia, April 14-16) (eds. Vnukov Ju. M.), Zaporizhzhia: ZNTU, vol. 3, pp.70-71.

8. Shytikova L.V., Gholovatenko S.S. (2015) Formuvannja upravlinsjkogho potencialu pidpryjemstva - kljuchova zadacha upravlinnja [The formation of the enterprise management capacity - the key aim of management]. Naukovyj visnyk Uzhghorodsjkogho universytetu. Serija «Ekonomika», vol. 2(46), pp. 257-260. 